\title{
Forging the Batavian Citizen in a Post-Terror Revolution
}

Reflecting upon the 'anarchic reign of terror', the August 25, 1796 issue of $D e$ democraten (The Democrats), the leading and theoretically most sophisticated political journal of the Batavian Revolution, called attention to 'the emphatic lesson in the history of the French, expressed through the blood of so many philosophers and Patriots'. This lesson, the journal urged, must be a 'signpost to the friends of true freedom, political order, and civil security'. ${ }^{1}$ Most Batavian revolutionaries at the time, as well as Orangists, for that matter, would probably have concurred with the journal's word of advice. Over the course of the 1790s, for many publicists and politicians, including the main contributor and co-editor-in-chief of De democraten, Willem Anthonie Ockerse, the Terror came to serve as an important reference point in political debates about the future architecture and political form of the newly founded Batavian Republic. Many of those who reflected on the Terror still held on to the Ciceronian view of history as Magistra Vitae, the teacher of life. Like so many American citizens on the other side of the Atlantic, they came to view the radicalization of the French Revolution, and the violent chapter of the Terror in particular, as history in the making, indeed, as a recent history that held many lessons in store. ${ }^{2}$

The circumstances in which the Dutch reflected upon the outbreak of the French Revolution, its radicalization, and its resort to terror, however, were very different from those in the early American republic. Even if, as we have seen, there was widespread disagreement and intense conflict among Americans about the accomplishments, or, conversely, the unfinished business, of their revolution, the early American republic of the $1790 \mathrm{~s}$ was still a postrevolutionary society in ways that the Dutch Republic clearly was not. In the late 1780s, the Dutch Republic witnessed the crushing of the democraticrepublican Patriot Movement (that had drawn inspiration from the American Revolution), and the restoration of the oligarchic Orangist regime of Stadholder

1 De democraten, vol. 1, no. 11, August 25, 1796, pp. 81-88, at p. 82.

2 By many the study of history was still seen as capable of providing lessons, even when the Terror was then 'contemporary' history, situated on the same historical plane. R. Koselleck, 'Historia Magistra Vitae. Über die Auflösung des Topos im Horizont neuzeitlich bewegter Geschichte', in: idem, Vergangene Zukunft, pp. 38-67. Cf. P. Fritzsche, Stranded in the Present. Modern Time and the Melancholy of History (Cambridge, MA: Harvard University Press, 2010). 
Willem V. The Batavian Revolution only broke out in early 1795, after the downfall of Robespierre and the Jacobin regime. The overthrow of the Orangist regime of Stadholder Willem V was made possible by Thermidorian France and executed by a combined army of Patriot exiles and French soldiers. The Batavian Revolution was a post-Terror revolution inspired by the very same revolution that had slid into terror.

The framework in which Dutch public debate about the radicalization of the French Revolution took place during the 1790 s was, thus, marked by a decisive rupture, the revolution of 1795 . One consequence of the overthrow of the Orangist regime was the brushing aside - at least for the time being - of the Orangist regime as a viable political model. A second, related implication of the new political reality was that the central ideological conflict in the public sphere was no longer played out between Orangists and revolutionaries. Instead, the gravitational centre of public debate shifted toward the differences of opinion about the future institutions of a new republic among Batavian revolutionaries themselves.

Another major difference between the American and Dutch contexts was that the Batavian experiment took place under the umbrella of the French Revolution. Over the past four decades or so, historians have rightly stressed the considerable extent to which Batavian revolutionaries could operate autonomously; the Dutch never simply served their apprenticeship in the art of revolution with French revolutionaries. ${ }^{3}$ Yet the French physical and intellectual presence was incontestably more intense in the Dutch than in the American republic. Under the Treaty of The Hague signed in May 1795, the Batavian Republic was obliged to pay France the astronomical amount of 100 million guilders as indemnity payments and to provide France with ships and troops. A secret clause required the Dutch to station and maintain 25,00o French troops on their soil, an army bigger than General George Washington ever commanded. Although the 1795 alliance treaty ensured French recognition of

3 Until the political breakthrough of January 22, 1798, forced by a group of radical republicans, and the subsequent acceptance of the constitution that established a unitary centralized state a few months later, the French kept a relatively low profile. After the second coup d'état of June 1798, and particularly after Napoleon's seizure of power on November 9, 1799, however, the Dutch increasingly lost room for political manoeuvre. In 1801, the French installed a more authoritarian and docile regime resembling the French Directoire, which in turn was replaced in 1805 by a single-headed regime under raadpensionaris (Grand Pensionary) Rutger-Jan Schimmelpenninck. A year later, Napoleon Bonaparte bluntly turned the Dutch Republic into a kingdom to be ruled by his brother, king Louis Napoleon. The Netherlands entirely lost their national sovereignty with their annexation in Napoleon's Empire in 1810, only to gain independence again after Napoleon's defeat in the Battle of Leipzig in late 1813. 
the Batavian Republic's independence, their military proximity strengthened the impression that the French could not be unambiguously hailed as liberators nor could their model be followed uncritically. From the beginning the Batavian revolution was coloured by the Jacobin experience. ${ }^{4}$

A crucially important explanation of the Terror that surfaced time and again pointed to France's lack of a sound constitutional order. This analysis became instrumental within democratic-unitarist arguments in favour of drawing up a national constitution for the new Batavian Republic. ${ }^{5}$ Its constitutional embedding came to be regarded as pivotal to citizenship. Whether the centralized unitary state established by the constitution of May 1, 1798, and its underlying ideals, was an authentic Dutch product of long-term internal developments or French import has long preoccupied the Dutch and international historiography of the Batavian Republic. However, this is in a sense a question mal posée. After all, Batavian revolutionaries realized from the very beginning that the mother republic had bequeathed an ambiguous example to them. Both for French Thermidorians and Batavian revolutionaries, the legacy of the French Revolution was troubled, not uniform. In the language of the time, the French Revolution was both a 'college of patriotism and revolutionary education', as the Dutch publicist Gerrit Paape famously put it, and a 'college of revolutionary disaster', as the former Patriot exile and representative Johan Huber declared. ${ }^{6}$ An unreflective import of French ideals was never an option.

The Terror came to be described as a typically 'French' phenomenon that had to do with the national character of the French people. Many Batavian revolutionaries were in agreement that something like the Terror was not to be expected in the Batavian Republic - and in fact, had not taken place. There was therefore no reason to follow the 'French' institutional and political response to the Terror. Accordingly, the Terror was set apart from the Dutch revolutionary experience. What was needed instead was a constitution for the Dutch and a Dutch model of citizenship.

4 Students of Dutch (both Orangist and Batavian) political thought of the 1790 s have generally neglected this question, or have only mentioned Dutch reflections on the Terror fragmentarily. See however, E.O.G. Haitsma Mulier, 'De receptie van de Franse Revolutie in Nederland. Contemporaine reactie en geschiedschrijving', Tijdschrift voor Geschiedenis 102 (1989), pp. 451-470; J. Oddens, Pioniers in schaduwbeeld: het eerste parlement van Nederland 1796-1798 (Nijmegen: Vantilt, 2012), pp. 126-128, 265-270.

5 Note that 'unitarist' in this context means favoring a unitary, centralized state. It has nothing to do with the theological doctrine of Unitarianism.

6 G. Paape, De onverbloemde geschiedenis van het Bataafsch Patriottismus van deszelfs begin (1782) tot op den 12 Junij 1798 toe (Delft: M. Roelofswaart, 1798), p. 123; Dagverhaal 4, no. 368, February 9, 1797 (session February 6), p. 793. 
This chapter, thus, clarifies the process through which the concept of citizenship became 'nationalized' during the Batavian Revolution. According to Niek van Sas, one of the leading experts of the period, the Batavian revolution's political construct of the Dutch national citizen was the culmination of a process of cultural nation formation that took place in the second half of the eighteenth century. 1798 was 'the political consequence of a process of cultural unification that had been going on for decades under the banner of the Dutch Enlightenment.' ${ }^{7}$ Van Sas has argued that after a short, but intense period of revolutionary radicalism and profound political conflict in 1798 , a clearly identifiable phase of moderation and national reconciliation set in after June 1798 . Without denying the importance of the cultural and enlightened national identity formation of the decades preceding the Batavian Revolution, and the reconciliation of partisanship after the 1798 coups, I suggest another axis along which one can discern the articulation of a concept of citizenship in national terms. More specifically, I argue that the twofold response of Batavian revolutionaries to the Terror - incorporating its lessons versus setting the Terror apart as something peculiarly 'French' - contributed to the conceptualization of citizenship in national terms. ${ }^{8}$

By situating the Batavian Republic more firmly within a transatlantic context, this chapter thus reconsiders the relationship between the Batavian Revolution and the wider transatlantic 'age of the democratic revolution'. Yet, my perspective differs from both Palmer's model of conceptual unity and Jourdan's more pluralist model in which processes of transfer play an important part. Instead, I trace and emphasize the changing character of the sense of Dutch revolutionaries of being part of a transatlantic movement in terms of a dynamical historical process of convergence and divergence. This was neither simply a question of French import nor purely a result of autonomous, domestic processes. In what follows, I stress that the Terror was an important element in the Batavian framework of reference. The evaluations generated by the Terror paralleled reflections on the Terror in France and the United States. However, if the Batavian revolutionaries shared a similar conceptual horizon with the French and Americans and were confronted with similar problems, the specific ways in which the Terror was invoked and reflected upon was determined by the phase and agenda of their own revolution as well as by the

7 Van Sas, De metamorphose van Nederland, p. 42.

8 This way of looking at nationalization is not incompatible with Van Sas's account. In fact, Van Sas sometimes hints at nationalization in opposition to the French, but not in any systematic way. Van Sas, De metamorfose van Nederland, pp. 30-31. 
national institutional and political-cultural background against which their revolution took place.

\section{Portraying the Terror between Orangist Restoration and Batavian Revolution}

Before we turn to the representation of the Terror in Dutch media, pamphlets, and journals, a few remarks on the political landscape of the late 1780 s and early 1790 are in order. The restoration of the Orangist regime headed by Stadholder Prince Willem V of Orange in September-October 1787 had involved violent punishments, the plundering of thousands of houses, and molestations of members of the Patriot Movement carried out by supporters of the Orangist regime. The States-General, provincial state, and city councils, but also lower echelons of the civil service, were purged from Patriot influences. Although no killings occurred, this 'Orangist Terror', as historian Joost Rosendaal has called it, was instrumental for the take-off of the stream of refugees in 1787-1788. Around 5,00o refugees fled to the Southern Netherlands, then under the rule of the Austrian-Habsburg Emperor Josef II, either as pit stop to northern France and Paris, or as a permanent place of exile. Ironically, instead of securing a stable power base, the unchecked ransacking and violence, as well as the processes and purges that accompanied the Orangist restoration, alienated many Dutch citizens from the restored regime. ${ }^{9}$

The conditions in the Dutch Republic for an open and public debate about the French Revolution were quite different from those in the United States. Under the Orangist regime restored by the intervention of Prussian armies in 1787 there was, first of all, no liberty of press. The Patriots who had decided to stay in the Dutch Republic had gone underground. The highly politicized Patriot journals that had mushroomed in the period $1780-1787$ and had revolutionized the Dutch (periodical) press were banned. Although after some time a general amnesty was granted to former Patriots, many editors and writers were exempted from it. ${ }^{10}$ Nonetheless, Orangist censorship was far from watertight. It was simply impossible to prevent the circulation of writings from Patriot refugees in France and foreign presses through a multitude of

9 Geyl, Geschiedenis Van De Nederlandse Stam, vol. 3, pp. 183-200; J. Rosendaal, Bataven! Nederlandse vluchtelingen in Frankrijk 1787-1795 (Nijmegen: Vantilt, 2003), pp. 33-54.

10 N.C.F. van Sas, 'The Netherlands, 1750-1813', in: H. Barker and S. Burrows (eds.) Press, Politics and the Public Sphere in Europe and North America, 1760-1820 (Cambridge: Cambridge University Press, 2002), pp. 48-68; Rosendaal, Bataven!, pp. 50-54. 
correspondence networks ran by the Patriot underground movement. ${ }^{11}$ In 1789 , for example, an abridged address of the abbé Sieyès on the Rights of Man and Citizen could be published unhindered in one of the leading Dutch spectatorial magazines. ${ }^{12}$ As the Orangist restoration rested on a precarious political foundation, and a widespread need for some kind of reform was felt throughout society, even by urban and provincial ruling elites of Orangist stripe, brutal repression was also unfeasible. The outbreak of the French Revolution, as well as the Brabant Revolution of $1789^{-1790}$, did much to stir up the flickering hope among former Patriots that the path of reform taken in the Patriot Era could and would ultimately lead to a major political transformation. The spectacular developments in France unmistakably proved the viability of Patriot aspirations. What was once considered a petty local movement, easily crushed by a highly professional Prussian army, suddenly seemed to have been part of a larger transnational revolution, a revolution that could now be resumed with the help of revolutionary France. Just like American citizens who after 1789 could reinterpret their own revolution, so the cause of former Dutch patriots was elevated, at least in their political imagination, to partake in a grand affair of world-historical importance.

Although press coverage in Dutch newspapers and journals of the various events of the French Revolution was remarkably detailed, it did not meet with widespread response or elicit strong opinions between 1789 and $1792 .{ }^{13} \mathrm{~A}$ turning point was August-September 1792, when the French constitutional monarchy was terminated, the September massacres took place, the battle of Valmy was won, and the French Republic inaugurated. Conservative commentators soon inferred that the revolution in France had taken a sinister turn. In midSeptember 1792, the Dutch 's-Gravenhaagsche Courant (The Hague Daily), a widely read, fairly pro-Orangist newspaper, suggested that with the king being suspended it is 'the rabble which at present rules despotically and decides on life and death. Commenting on the massacres that took place in and around Parisian prisons in early September, the reporter lamented that 'thinking about all the terrible horrors which have taken place in this state and the capital in

11 Schama, Patriots and Liberators, pp. 141-142; Haitsma Mulier, 'De receptie van de Franse Revolutie'.

12 Bijdragen tot het menschelijk geluk II, no. VI (1789) pp. 420-426. According to the editor, it had already appeared in the Vaderlandsche Bibliotheek van Wetenschap, Kunst, en Smaak I, no. 8, p. 353. The address in question was Sieyès' Préliminaires de la Constitution: Reconnaissance et exposition raisonnée des droits de l'homme et du citoyen, 20 et 21 juillet 1789, Comité de Constitution.

13 W. Frijhoff, M. Jongedijk, and R. Rottier, 'Vryheid of de Dood'. La Révolution française vue des Pays-Bas, 1789-1798 (Amsterdam: Maison Descartes, 1789), p. 18. 
particular makes one's hair stand on end'. The same week, a Haarlem newspaper reported that 'the streets, especially in the vicinity of the prisons, are covered with mutilated corpses'.14

Dutch responses to the increasingly violent and radical character of the French Revolution appeared at a precarious moment for the Dutch Republic. On February 1, 1793, France declared war to the Dutch Republic. By the end of February, French troops under command of General Dumouriez had seized Breda in Brabant, preparing to march on to Dordrecht. They were, however, quickly driven back by Austrian troops. By late March, the French did not pose a direct threat to the Orangist regime anymore, at least for the time being. But the threat of invasion - or prospect of liberation - and the unpredictable and chaotic course of events in France provoked a stream of publications from different sides.

One category within this stream of publications were very partisan booklets, some instructive, some more poetic, as well as children manuals and almanacs. In the richly illustrated Dutch booklet De gruwel der verwoestingen of Vrankryks moord- en treur-toneel (The Horror of the Ruins of France's Theatre of Murder and Grievance), for example, which was intended as a 'warning and spectre for all peoples of Europe', but especially for 'Dutch inhabitants', a bleak image was painted of what the author described as 'French Liberty and Jacobin Equality'. The explicit motivation behind the booklet was the publication earlier that year of an 'almanac' containing four poems commemorating scenes of the French Revolution and the military campaign into the Southern Netherlands led by the French 'citizen-general' Charles-François Dumouriez. In the pro-revolutionary almanac, the 'brave' French people were described as having been suppressed by nobility and clergy for too long, the abolishment of the monarchy as comparable to the Dutch Revolt against the Spanish king, and Dumoriez as a courageous leader, his portrait embellished with pictures of battle scenes and people dancing around the freedom pole. ${ }^{15}$ De gruwel der verwoestingen was meant as a visual counteroffensive against this dangerous pro-revolutionary propaganda. The popular siege of the royal palace and the prison massacres were construed along the narrative of a revolution in moral and political decay. While the earlier storming of the Bastille was still described in affirmative terms, even as an 'act of heroism', the theme that dominated the

14 s'-Gravenhaagsche Courant, September 12, 1792; Haarlemse Courant, September 15, 1792. Both cited in:J.W. Berkelbach van der Sprenkel, 'De Franse Revolutie in de contemporaine Hollandsche Couranten', De Gids 103 (1939), pp. 323-357, at p. 349.

15 Gedenkwaardige brieventas almanach voor het jaar MDCCXCIII (n.p., 1793), Streekarchief Midden-Holland, ref. nr. 0200.630. 
booklet's pages was mob violence and atrocities committed in dark moments of popular rage and anarchy. Almost every visual representation of the events of the Revolution contained seething crowds or acts of mob violence. ${ }^{16}$ Yet, like many American in the early 179os, Dutch commentators were simply astounded by the course of events in France. Even within the bleakest pages of this expressive piece of visual anti-revolutionary rhetoric the authors confessed that 'No one familiar with the nature of the French people' - the 'people of vive le roi' - could have 'imagined from the principles of revolution that things would rise to such great heights.' ${ }^{17}$

Dutch patriots at home supporting the French Revolution felt that they could not remain silent about the reports of violence from France. They faced the challenge of carrying through a 'radical' revolution without being associated with the 'radical' French Jacobins. Pieter Paulus, in his 1793 Treatise on Equality that would become the most important and influential treatise of the Batavian Revolution, the bulk of which was written in 1791, devoted an extensive footnote (written in late 1792) to the 'misfortunes' of France in which he acknowledged that the revolution in France was by now incontestably 'tarnished. Tellingly, Paulus blamed the calamities in rather imprecise terms on the inability of the French king and the National Assembly to collectively devise a stable form of government based on the rights of man. ${ }^{18}$

Another early example of a future revolutionary responding to the increasingly violent character of the French Revolution was Ockerse, an eccentric clergyman who in $1786-87$ had supported the Patriot Movement (if more in word than in deed), and would become the leading Batavian revolutionary of the first coup and constitution of 1798. Inspired by the revolution in France, in the early 1790 os Ockerse openly declared that he was in favour of a drastic political reform of the Orangist regime. A vehement pamphlet from his pen appeared in 1793 entitled De Constitutie der Franschen verdedigd tegen de lasterlijke grondbeginsels van de leden der Sociëteit in de Kroon en het Anker te Londen vergaderende (The French Constitution defended against the Slanderous Founding Principles of the Members of the Society Meeting in the Crown and Anchor in London), written in response to the founding manifesto of the London based Association for the Preservation of Liberty and Property against

16 De gruwel der verwoestingen, of Vrankryks moord- en treur-tooneel: Ter eeuwiger gedachtenis vertoond in een aantal fraaije afbeeldingen en naauwkeurige verhaalen van de voornaamste gebeurtenissen, geduurende de jongste revolutie in het ongelukkig Vrankryk voorgevallen. Ten leer- en schrikbeeld voor alle volken van Europa, en inzonderheid voor Neêrlands ingezeetenen (Amsterdam: J. Peppelenbos, 1794), pp. 6, 15.

17 De gruwel der verwoestingen, pp. 121-122.

18 Paulus, Verhandeling over de vrage, p. 153. 
Republicans and Levellers. ${ }^{19}$ The intended purpose of Ockerse's pamphlet was a refutation of what he called the Society's 'declaration of war' against 'the giant of Liberty and Equality' (i.e. the French Republic). ${ }^{20}$ This notorious manifesto, he noted, had caused quite a stir in government gazettes as well as ordinary newspapers 'both within and outside England'. With his own pen 'dipped neither in the gall of Anchor and Crown nor in that of the Jacobin mind', Ockerse conceded that 'the civilized French nation for some time now has degenerated into Cannibals, possess neither fairness nor faith, and solely preys on blood and tears.'21 There was no denying that the gloomy succession of disastrous events had cost thousands of lives. 'Surely not one European people, how heavily oppressed, how deeply humiliated, how cruelly mistreated, would even for a moment have reason to wish that something of that nature would take place in his country.'22 That said, there was equally no doubt on his mind that recorded history had never seen a revolution without bloodshed. To Ockerse it did not seem all that surprising to see a revolution go hand in hand with such 'convulsions' in a country that, after all, 'for more than a century has been ravaged by the scourges of an infernal despotism. ${ }^{23}$ In the end, the only people to be really blamed for the revolutionary bloodshed were, according to Ockerse, the French Bourbon kings and those who under their reign had 'corrupted' the French state. Against the background of decades of slavish subordination, it was quite understandable that the people would succumb to excesses, even more so since the revolution was thwarted by 'growing opposition' and other 'obstacles', as well as 'internal treason', threats of 'foreign violence', and 'counterrevolution'. ${ }^{24}$ Summing up these mitigating circumstances served to make one point crystal clear: the excesses of the French Revolution were not a result of the principles of the French constitution as the Crown and Anchor clique had suggested, but an aberration due to various other circumstances.

19 The London based 'Association for the Preservation of Liberty and Property against Republicans and Levellers' was founded on November 20, 1792, by the civil servant and legal scholar John Reeves (1752-1829) and had its meetings in the Crown and Anchor tavern. On this association, see H.T. Dickinson, 'Popular Conservatism and Militant Loyalism, 1789-1815', in: idem (ed.) Britain and the French Revolution, 1789-1815 (Basingstoke: Macmillan, 1989), pp. 103-126; M. Philp, 'Vulgar Conservatism, 1792/3', in: idem, Reforming Ideas in Britain. Politics and Language in the Shadow of the French Revolution, 1789-1815 (Cambridge: Cambridge University Press, 2014), pp. 40-70. van de leden der Sociëteit In de Kroon en het Anker te Londen vergaderende (z.p., 1793), p. 3. [W.A. Ockerse], De Constitutie der Franschen, p. 21.

22 Ibid., p. 37.

23 Ibid., p. 38.

24 Ibid., pp. 39-40. 
Yet, news of the ensuing violence and chaos in France made even the most fervent Dutch supporters of democratic reform feel uneasy. Among them was Samuel Wiselius, regarded by many historians as one of the driving intellectual forces behind the reformulation of the Patriot - into the Batavian - political agenda in the early $1790{ }^{25}{ }^{25}$ Between 1789 (at the age of twenty) and 1793 he delivered three bold lectures in front of bustling audiences at the Amsterdam based heavily politicized literary society Doctrina \& Amicitia. This society has rightly been described as the 'intellectual centre of the Patriot Movement, from whence the Batavian Revolution of 1795 would largely be prepared' ${ }^{26}$ In his lecture Proeve over de verschillende regeringsvormen in derzelver betrekking tot het maatschappelijk geluk (Treatise on the various Forms of Government in their Relation to Public Happiness) delivered in early 1793, Wiselius submitted the democratic form of government to a critical examination. The attentive listener could not fail to detect the hidden references to the situation in France. 'Absolute democracies' (volstrekte Demokratien), Wiselius said, 'are always liable to manifold ruptures and disturbances'. Only at the end of his exposition he cautiously suggested to 'cast a glance at a large neighbour nation, to...', but Wiselius broke off his sentence and continued: 'However, I don't want to engage in speculation, which, even though grounded, may give offence to some.'. ${ }^{27}$ Looking back on his lecture some three decades later, Wiselius, recalled the 'current' against him, 'being denounced so sharply' that he decided to stow away his address as it was declared 'antipopular, aristocratic, and entirely oldfashioned': ${ }^{28}$ Even within Dutch pro-revolutionary circles striking the right balance between praising the principles of the French Revolution, and disapproving of the excesses of 'absolute' democracy was a delicate business.

Finally, a number of Patriot exiles lobbying in Paris for French support for the launch of a revolution in the Dutch Republic, who would come to play a role in the Batavian Revolution, witnessed the radicalization and political violence of the French Revolution from close by. Naturally, reconciling the glorious 'cause of liberty' allegedly shared by French and American citizens, with the 'dreadful excesses' was a major challenge to them. The Catholic patriot and former mayor of Eindhoven (Staats-Brabant), Jan van Hooff, co-founder in October 1792 (together with Johan de Kock and Pierre Alexandre Dumont-Pigalle)

25 Leeb, The Ideological Origins of the Batavian Revolution, pp. 229-251; De Wit, De strijd tussen aristocratie en democratie, pp. 83-93, 319-336; Van Sas, De metamorphose van Nederland, pp. 208-281, 307-308; Velema, Republicans, p. 188.

26 De Wit, De strijd tussen aristocratie en democratie, p. 85.

27 S. Wiselius, Proeve over de verschillende regeringsvormen in derzelver betrekking tot het maatschappelijk geluk (Leiden: S. en J. Luchtmans, 1831), pp. 25, 31.

28 Wiselius, Proeve over de verschillende regeringsvormen, vii-viii. 
of the Comité Revolutionair der Bataven (Batavian Revolutionary Committee), is a case in point. As member of the Revolutionary Batavian Committee which was formally acknowledged by the French National Convention in late October 1792 and was instrumental in rallying the French behind their plan to invade the Dutch Republic, Van Hooff co-authored a manifesto that sought to prepare the Dutch mind for a regime change. However, after the defeat of the French armies against the Austrians in March 1793 and the desertion of General Dumouriez, a Girondist with whom the Batavian Revolutionary Committee had closely cooperated, the Committee was disbanded. The radicalized Jacobin faction, purged of its Girondin members, came to look upon the Batavian Committee's members with suspicion. Van Hooff, imprisoned in the former Collège des Irlandais and later in the Palais du Luxembourg, barely escaped the scaffold during the great Terror of June-July $1794 .{ }^{29}$ With the dawn of Thermidor, he was released in early November. His close associate De Kock was less fortunate and was guillotined in the purge of the Hébertists in March 1794. Perhaps not surprisingly, when Van Hooff secured a seat in the Batavian National Assembly in 1796, he would become one of the most outspoken critics of the excesses of the Jacobin regime.

At least eighteen representatives of the first National Assembly (12\%) had spent some time in the French epicentre of revolution. But only a handful of exiles - Van Beyma, Van Hooff, Valckenaer, Blok, and Bicker - held a prominent place in the National Assembly's meetings. Joris Oddens has maintained that the former exiles 'interpreted the French experience just as varied as the representatives who did not spend the [Orangist] restoration in France. ${ }^{30}$ In other words, there does not seem to be a clear correlation between the radicalism of the representatives and their sojourn in revolutionary France. Yet, as we will see, future Batavian revolutionaries such as Van Hooff drew on their own observations and experience of revolutionary politics in Paris to critically reflect on the workings of the Jacobin clubs.

As was to be expected, from the Orangist ranks the popular democratic tendencies of the French Republic were criticized in much harsher terms. Adriaan Kluit, the most prominent Orangist publicist and counterpart of Paulus at the time, in late 1793 cynically remarked about the September prison massacres that the act of 'septembriseeren' by an 'inflamed crowd' - 'that is, in the current parlance of Liberty, dragging the prisoners out of prison on the street, one by one, guilty or not guilty, and letting the people tear them apart' - was something even a malicious king had never undertaken. But the ' 500 or 600 men' of

29 Rosendaal, Bataven!, p. 420.

3o Oddens, Pioniers in schaduwbeeld, pp. 127-128. 
the new Convention that had replaced the king as the 'people's representative' were now 'applauded' for it. ${ }^{31}$

That same year the Leiden city magistrate, bibliophile, and Holland deputy for the Dutch States-General between 1793 and 1795, Johan Meerman published an anti-revolutionary tract which devoted considerable space to an analysis of course of the French Revolution. In his De burgerlyke vryheid in haare heilzaame, de volks-vryheid in haare schadelyke gevolgen voorgesteld, inzonderheid met betrekking tot dit gemeenebest (Civil Liberty with its Beneficial, Popular Liberty with its Harmful Consequences presented with Special Reference to this Commonwealth), Meerman took explicit aim at what he called 'popular or political freedom', offering a stinging critique of the democratic practices he observed in the French capital. ${ }^{32}$ Meerman's critique of popular democratic practices in France was not simply reactionary slander. On closer inspection, it articulates a line of argumentation that also resonated with French and American reflections on the Terror, even with what more moderate Batavian revolutionaries would come to argue. During meetings of the French representative assemblies, a form of 'public consultation', Meerman wrote, the 'galleries of the assembly' were 'packed with paying spectators promoting the interests of that party that filled their bellies'. These meetings were saturated with 'improper cheers and clapping', 'corrosive grumbling and laughter', and sometimes even 'death threats' addressed to representatives at the assembly hall's entrance. Ever since the first meetings of the National and Legislative assemblies, Meerman asserted, 'France has not been at liberty for one single hour'. He was especially critical of the Paris-centeredness of all political activity: 'Instead of the deputies of the entire people', it was Paris that ruled. ${ }^{33}$

Meerman singled out the political clubs as especially anti-democratic, as the decrees that were to be submitted to the 'supreme assembly' were already 'forged' in the political 'societies. ${ }^{34}$ In combination with the 'vengefulness' and 'avarice' of demagogues manipulating the public, the politics of these clubs proved to be a recipe for disaster and the cause of the continuous recurrence of 'dehumanizing scenes'. The inconstancy of the people was, moreover, displayed by the fact that where Necker and Lafayette were first hailed as heroes, they were then quickly despised as enemies of the people. ${ }^{35}$ All things

31 [Kluit], De rechten van den mensch in Vrankrijk, p. 99-100.

32 J. Meerman, De burgerlyke vryheid in haare heilzaame, de volks-vryheid in haare schadelyke gevolgen voorgesteld, inzonderheid met betrekking tot dit gemeenebest (Leiden: Luchtmans, 1793), p. 4.

33 Meerman, De burgerlyke vryheid, p. 39.

34 Ibid., p. 40.

35 Ibid., p. 41-42. 
considered, the new political system could hardly be called a genuine democracy according to Meerman. It was a political minority that ruled 'over the larger, conquered mass of silent and calm inhabitants'. The fundamental problematic concept was the citizens' newly acquired political liberty: 'Political liberty is by nature - I cannot find words to express my conviction powerfully enough - the exterminator, the eradicator, the murderer of civil [liberty]. ${ }^{36}$

What is remarkable about Meerman's attack on political liberty is that he condemned the French revolutionary government for making a travesty of the principles of transparent democratic governance and public debate. The critique he advanced was not so much anti-democratic in nature - what might be expected from an Orangist publicist. Rather, he argued that the French revolutionary government was bullied by popular clubs that were hardly transparent and in practice denied Frenchmen outside Paris equal democratic participation. At first sight, it makes sense to dismiss Meerman's 'pro-democratic' critique of the French representative democracy as a rhetorical move, an opportunistic argument well-suited for the occasion. After all, Orangist publicists in the 1780 s and 179 os were not particularly well known for their democratic sympathies. However, Meerman was fully aware that after the outbreak of the French Revolution, some degree of reform and opening up of the Dutch ruling elite was unavoidable, and to some extent desirable. In this he was not alone. In his unpublished writings, the future constitutional architect of the constitutional monarchy of 1814-1815, Gijsbert Karel van Hogendorp also criticized the poor constitutional makeup of the French Republic. ${ }^{37}$ Considered within a transatlantic context of perceptions of the Jacobin Terror, Meerman's analysis actually turns out to be very much in line with a broader post-Terror rejection of political clubs and advocacy of robust constitutional safeguards.

2

\section{Limiting Power, Protecting Rights: The Terror and the Need for a Constitution}

In mid-January 1795, French-Batavian troops crossed the great frozen rivers of the Waal and the Lek and marched north. In an unguarded moment at night, the Stadholder and his retinue hastily fled to England. Soon former patriot

\footnotetext{
$36 \quad$ Meerman, De burgerlyke vryheid, p. 42.

37 See, for instance, G.K. van Hogendorp, Gelijkheid der menschen (door Pieter Paulus) wederlegd. Een fragment denkelijk 1793. Nationaal Archief, Collectie Van Hogendorp, 2.21.0o6.49, Inv. nr. 71-f; G.K. van Hogendorp, Omwendingen (na de Fransche Revolutie) IIde, IIIde, en IVde hoofdstuk. Nationaal Archief, Collectie Van Hogendorp, 2.21.006.49, Inv. nr. 71-m.
} 
citizens in cities and towns in Utrecht and Holland deposed the sitting city councils. Although in some places, Zeeland province especially, revolutionaries met with more resistance from local governments, the regime change generally occurred without violence. By the end of February, the Statenvergaderingen (provincial councils) were replaced by provisional assemblies of representatives. The Provisional Assembly of the Representatives of Holland took on a leading role by declaring openly the 'people's sovereignty' and the 'unalienable rights of man'. On January 31, the Holland Assembly issued the first Dutch declaration of the rights of man and citizen. ${ }^{38}$

The first, chief political issue to be tackled after the overthrow of the Orangist regime in early 1795 was the formation of a national convention. The supreme political authority of the federative Dutch Republic was - on paper still the States-General, an assembly composed of representatives of the provinces that were largely autonomous. Despite swelling public opinion in favour of a new state structure based on the principle of 'één- en ondeelbaarheid' (unity and indivisibility), proposals for a national convention met with firm opposition, in particular from the side of the members of the provincial assemblies of Zeeland, Friesland, and Groningen. Various proposals advocating a unified state structure, and the formation of a national assembly to bring such a unified state about, had been worked out by Patriot exiles as early as 1789. However, on the whole these plans did not provide for a detailed plan of how the formation of a national convention should take place. If this national convention should come up with a new constitution, as most Batavian revolutionaries agreed, what should be its status prior to the eventual adoption of a new constitution? Moreover, what ought to be the nature of the mandate of the representatives that were to make up this new convention? Should they be 'independent' representatives, without 'last en ruggespraak' (instruction and obligatory consultation), representing one sovereign Dutch nation, or were the provincial assemblies to have a final say in the matter? ${ }^{39}$

In early 1795 , in what would become a controversial pamphlet, Ockerse made a passionate plea for a national convention. He explained that opponents fearing a recklessly instituted powerful and independent national convention often referred to the French example for guidance. According to these opponents, the French National Convention was the source of the 'tragedies'

38 For an analysis, see Jourdan, La Révolution batave, pp. 106-108; W.J. Goslinga, De Rechten van den Mensch en Burger: een overzicht der Nederlandsche geschriften en verklaringen (The Hague: A.J. Oranje, 1936), pp. 86-107.

39 Oddens, Pioniers in schaduwbeeld, pp. 82-100; Schama, Patriots and Liberators, pp. 211-244. 
France had suffered. Yet, the tragedies of France, Ockerse replied, had more to do with the influence of the French king, the 'agitation of the clergy', and the 'villainy of intriguers'. The reign of Terror under Robespierre was not a consequence of the transfer of political power to a national convention, but an aberration of otherwise sound principles. 'Should we reject the good in its totality, because it has been ill-used?', he asked. As France had moved beyond the Terror and taken a moderate turn, Ockerse felt he now could safely evoke the new French Thermidorian regime:

Do you not, does the Nat. Convention not have a newly approved constitution to consult? Should we not have confidence that that people, experienced through blood and tears, cleansed the constitution of all despotic influence, have offered us a model that we for the time being could follow? ${ }^{40}$

Reflecting on the dawn of a bright new phase in the French Revolution, Ockerse thus considered it to be only logical to call upon the Dutch people to demand a national convention. Whereas in 1793 Ockerse had foregrounded 'circumstances' in his explanation of the French regime's resort to methods of terror, he now conceded that the bloody experience of the French Revolution had something to do with the very constitutional make-up of France, or rather the lack of it. The Jacobin regime's lack of constitutionality, and the new air of constitutionalism under Thermidor, thus, came to be invoked in arguments in favour of drawing up a new constitution. In Ockerse's journal De democraten of August 25, 1796, this line of analysis was carried forward:

The Democratic Constitution that was adopted in 1793 affirmed by experience that which had previously been taught by political philosophers: that an extended Republic cannot exist by way of a democratic order. Yet one still has to admit that the horrors committed by Robespierre and his followers were not necessary consequences of the Constitution of 1793; this constitution was rather a result or creation of their disorderly system. ${ }^{41}$

In a later issue of De democraten it was specified that, although the Jacobin constitution of 1793 might have been designed with 'good intentions' and

\footnotetext{
40 [W.A. Ockerse], Bataven! Eischt eene Nationale Conventie! of beroep aan het Bataafsche Volk (n.p., 1795), pp. 10, 13-14.

41 De democraten, vol. 1, no. 11, August 25, 1796, pp. 81-88, at p. 82.
} 
based on 'simple philosophical grounds', it lacked 'sufficient preservatives' against the 'abuse demagogues and anarchists made of it afterwards'.42 The history lessons of the Terror could, thus, be of great help 'to stem the tide of vices, debauchery, and deficiencies that may rise again with every blow of passions, fanaticism and intrigues. ${ }^{43} \mathrm{~A}$ sound constitution could check the power of a national legislation and prevent arbitrary use of power according to Ockerse.

What is crucial to observe is that by setting apart this extreme episode of the French Revolution as an 'aberration', unitarist-democratic revolutionaries such as Ockerse could dissociate their political agenda from Jacobin radicalism. In the process, if still in general terms, they forged a post-Terror conception of citizenship around the concepts of law and order, a new constitution for a unified state, and the alleged sobriety of the Dutch. Radical democratic-unitarist revolutionaries such as Ockerse, whose passionate pamphlet incited widespread disapproval, were keen to embrace the Thermidorian moment in France. More than anything else, Thermidor and its most important spokesperson Boissy d'Anglas, whose Discourse préliminaire was avidly read and appeared in Dutch translation, represented to them France's return to constitutional government. Not only radical republicans such as Ockerse, but also more moderate revolutionaries were able to appropriate parts of Boissy d'Anglas's republican discourse for their own revolutionary agenda aimed at the establishment of a constitutional republic (although in the course of the Batavian Revolution central elements of the Thermidorian constitution came to be rejected). ${ }^{4}$

Dissociating the Batavian cause from Jacobin radical politics was, for example, also the tenor of a letter to the editor in De republikein (The Republican), the other leading political journal of the early Batavian revolution, edited by Jan Konijnenburg, a prominent journalist and professor at a remonstrant seminary of democratic-unitarist hue (although he prided his own journal to give space to opinions that were not necessarily his own). The anonymous author of the letter actually argued against those who sought to resolutely wipe the institutional slate clean and give the national convention carte blanche. The formation of a national convention was absolutely necessary in his eyes, that is, as long as it was equipped with a clear and limited mandate. Given the heated public debates and the fresh memory of the Terror, the author felt it was necessary that the more deliberate advocates of the formation of a Dutch

42 De democraten, vol. 1, no. 38, January 26, 1797, pp. 277-284, at p. 280.

43 De democraten, vol. 1, no. 11, August 25, 1796, pp. 81-88, at p. 82.

44 Cf. Oddens, Pioniers in schaduwbeeld, pp. 242-262. 
'National Assembly' shake off the reputation of being unruly revolutionaries, lest the national convention would become tainted by association with 'socalled revolutionary government'. It was this form of revolutionary government, the 'scheme hatched by the tyrant Robespierre, through which tragic France was terribly shocked and so much innocent blood was spilled.'45 Honest and upright revolutionaries, the author maintained, know how to distinguish between the moment of revolution and the moment that freedom has actually been obtained. Moreover, they know how to distinguish between the (violent) means of bringing about a revolution and the means to consolidate it. Honest and upright revolutionaries too 'are horrified by injustice, persecution, and oppression' as well as 'revengefulness' against the 'errors and political crimes of former regimes'.

Anticipating the accusation that he was 'pro-Orangist', even 'Aristocrat', the author suggested that with his reconciliatory attitude he was actually in good company. He offered a lengthy quote from the Dutch translation of Thomas Paine's Dissertation on the First Principles of Government that had been published the previous year to back up his position. ${ }^{46} \mathrm{He}$ singled out the end of the pamphlet where Paine criticized France for not having adopted a constitution soon enough, a measure that otherwise would have prevented the country from falling into chaos and violence. Paine's - and the anonymous author's message was that man's desire for freedom, including the understandable desire to punish his enemies, must be institutionally curtailed, first and foremost by a constitution. The author went on to add another lengthy quote from, again, another recently translated foreign text: the Discourse préliminaire by Boissy d'Anglas. ${ }^{47}$ 'One will learn from it', he suggested, 'that his way of thinking is of a piece with that of Thomas Payne.' Boissy d'Anglas' speech not only advised to withhold from reckoning with political opponents. According to the anonymous author, it addressed a much broader subject: Jacobin democracy and the Terror. '[I]f we do not draw lessons' from Boissy d'Anglas' speech, he asserted, 'then we must blame ourselves in the case we, although duly and thoroughly warned, run upon the rocks of anarchy, exaggerated patriotism, popular demagogy and agitation. ${ }^{\prime 4}$ Like Ockerse, moderate voices like this letter in De republikein also sought to isolate the Terror, in order to dissociate the

45 De republikein II (1796), no. 57, p. 35.

46 T. Paine, Dissertation on the First Principles of Government (London: Eaton, 1795). Translated as Verhandeling over de eerste beginsels der regeering (Leiden: Murray and Loosjes, 1795).

47 F.A. de Boissy d'Anglas, Vertoog bij de aanbieding van het ontwerp van constitutie, voor de Fransche Republiek (Haarlem: F. Bohn, 1796).

48 De republikein, II, no. 57 , p. 38 . 
broader Batavian revolutionary project from Jacobin radicalism. The embedding of their cause within a reinvented transatlantic revolutionary agenda in which Boissy d'Anglas and Paine were presented as its moderate spokesmen, shows that the redefinition of citizenship through the prism of a constitution was informed by experiences and discourses that transcended national boundaries.

For the eminent legal scholar J.H. Cras, the overarching lesson Batavian revolutionaries ought to learn from the Terror was also constitutional, but in a slightly different way than Ockerse and the opinion article in De republikein claimed. In 1795, Cras opposed the establishment of a national assembly, that is, as long as the constitutional rules this new assembly should adhere to would not be determined first. One cannot assume, he argued, that citizens would elect good representatives and that, in turn, these representatives could be trusted unconditionally. The Terror was his main point of reference. 'The French Citizens, who elected Marat, Robespierre, and his followers were acting in good faith'. They turned out to be 'monsters' who were actually 'fellow citizens of the innocent victims they murdered'. But 'they could not have murdered [them]', Cras argued, 'had there been a Constitution, which would have restricted the power of the National Convention. 49

There was some truth to that observation. Although the French National Convention had approved the new Montagnard constitution of Year I on 24 June 1793, it was never implemented. From 10 August 1792 until 26 October 1795, the day on which the Constitution of Year III was put into effect, France was effectively being ruled by exceptional, or 'revolutionary government', as the Montagnard politician Saint-Just put it, that is, outside the framework of a constitution. Cras's argument was premised on this French experience. Without a robust constitution a centralized government could easily slid into terror.

Whereas Ockerse belonged to the democratic-unitarist strand of the Batavian political spectrum, building a case for a national convention that ought to come up with a constitution as soon as possible, Cras supported a centralized government but warned for a lack of constitutional checks. Yet, other voices could be heard too. Pragmatic federalists desiring a decentralized, federative state structure, such as Jan Henrik Swildens, also elaborated at length on the 'example' of France to elucidate their conceptions of constitution and

49 [H.C. Cras], Gewigtig advys over de vraag: moet eene constitutie de Nationale conventie; of een Nationale conventie, de constitutie voorafgaan? (n.p., n.d. [1795]), pp. 6-7. 
citizenship. ${ }^{50}$ In his Politiek belang-boek voor dit provisioneel tydperk (Political Interest Book for this provisional Age) published in 1795 , Swildens, a professor of natural and constitutional law at the Franeker Hogeschool and author of a number of key political publications of the Dutch Patriot Era, also tried to detach the Batavian Revolution from the Terror and take to heart the lessons it provided with regard to the question how a gradual reform of the existing political order should proceed. The series of astonishing events that had rocked the French nation could be of great help to Dutch revolutionaries, Swildens thought, as they could now 'look back wiser' and 'look forward more cautiously'. As he saw it, France's 'manifold' revolution was now 'mourning its fatal mistakes'. The country had been ravaged by a 'thousand headed Jacobin Monstrosity'; terror had been 'the order the day'. But perhaps, he suggested, the 'foundations' of a new political order must be sought in the 'ruins of destruction. 51

He accordingly offered a 'succinct list' of recommendations, literally 'after the example of France. ${ }^{52}$ Among other things, he insisted on the importance of law and order and equality before the law, which required a pragmatic constitutional outlook: 'we must return from feigned equality, which nature neither provides nor preserves, to such equality that [...] must be provided and forever safeguarded by civil ties and law and order'. In other words, 'we must return from what is constitutionally aesthetic for either the eye or in theory, to what is constitutionally useful. ${ }^{53}$ Admittedly, Swildens' recommendations were still quite vague, even cryptic. But they were perhaps for that reason also representative of a broader tendency among Batavian revolutionaries who wished to revise the idea of revolutionary citizenship in light of the Terror. A sound constitution was the principle means to arrive at a model of post-Terror citizenship.

\section{Channelling the Participation of the People}

While there was almost unanimous support for a constitution as the principle means to prevent a reign of Terror, the question of how to channel the political involvement of the citizenry was still open. Batavian revolutionaries were all in

50 In the Dutch context, Federalists were those who supported a decentralized confederal republic, which is the complete reverse of the American Federalist.

51 [J.H. Swildens], Politiek belang-boek voor dit provisioneel tydperk (Amsterdam: J.R. Poster, 1795), pp. 33, 39, 130.

$5^{2}$ [Swildens], Politiek belang-boek, pp. 107-108.

53 [Swildens], Politiek belang-boek, p. 131 . 
favour of democratizing the political system. There was, however, a great divergence of opinions about the ways in which and to what extent this democratization should be operationalized, especially given the recent French experience. What degree and kind of political participation is desirable? And what were the dangers of involving a broad citizenry in politics? The history of the Terror in France raised fears over the role of popular societies, preventing faction, keeping the rabble in check, and dealing with the fickleness of the people.

Broadly speaking, virtually all Batavian revolutionaries were in agreement that the new Batavian Republic ought to be governed by a system of elective representation. But, as has recently been pointed out in some detail, the nature and extent of the involvement of the people in a system of political representation was vigorously contested. Inspired by Rousseau, radical (unitarist) republicans such as Pieter Vreede and Bernardus Bosch incessantly emphasized the permanent sovereignty of the people. They insisted that the task of representatives - a term some in fact wished to see substituted for 'governors' or 'administrators' so as to emphasize the executive nature of representation - consists of executing the general will of the people, not forming it. In a representative system, according to these radical republicans, citizens organized in popular societies exercise their sovereignty by continuously monitoring, admonishing, and holding their representatives accountable.$^{54}$ Although the radical republicans who put forth this conception of citizenship represented an important and vocal voice, the majority of the Batavian revolutionaries subscribed to the idea of a more independent representative body, to whom the capacity of exercising popular sovereignty was transferred..$^{55}$

In addition, it is crucial to realize that the frequent calls for citizen's (civic) vigilance and political readiness, the emphasis placed on the vital function of political clubs and societies, and the stress on the ultimate and permanent sovereignty of the people, were forms of political mobilization rhetoric at a highly uncertain revolutionary moment (if revolutionary France had made one thing clear, it was that in revolutionary times nothing is certain). The revolutionary years between 1795 and 1798 were not only theoretically, but also institutionally and politically fluid. There was no constitution yet, and the National Assembly was not an ordinary parliament but a constituante, a constituent assembly. According to the radical republicans, the Batavian Republic remained in a state of

54 W.R.E. Velema, 'Republikeinse democratie. De politieke wereld van de Bataafse Revolutie, 1795-1798', in: Grijzenhout, Velema, and Van Sas (eds.) Het Bataafse experiment, pp. 27-63, esp. pp. 46-51; Rutjes, Door gelijkheid gegrepen, pp. 77-8o. Other radical republicans advocating permanent civic participation were representatives Court Lambertus van Beyma and Jacob Hahn.

Cf. Koekkoek, "Eene waare en vrije republiek"'. 
revolution until the acceptance of a new constitution would end it. ${ }^{56}$ Politicians were forming coalitions, trying to put pressure on opponents and potential allies, and seeking public support. We should, in short, be cautious to interpret revolutionary republican rhetoric simply as programmatic statements about a post-revolutionary order.

The crux is that most Batavian Revolutionaries felt that such platforms for (revolutionary) citizen activity only had a temporary role to play. Before 1795, Wiselius, for instance, had been rather critical of the 'manifold ruptures and disturbances' in France caused by unsound democratic practices. But in the Spring of 1795, when he had been chosen as Amsterdam's representative for the Provisional Assembly of Holland, he was all too eager to invoke the help of grass-roots democratic forces. In Wiselius's estimation, the volksvergaderingen (municipal popular assemblies) of Amsterdam were the democrats' backbone against the city's conservative bulwark of patrician regents. He noted that they were 'the best support for friends of the people, for pure democrats, who aim at unity and indivisibility'. However, after January 1798, once the unification of the Dutch state was forced through, Wiselius made multiple efforts to close 'these disastrous deliberating primary assemblies. ${ }^{57}$ Revolutionaries such as Wiselius, as well as Gogel, Ockerse, and many other prominent publicists and politicians, were convinced that tranquil and learned gatherings of enlightened citizens (among whom they counted themselves) in equally cultivated premises were perfectly legitimate, and must be carefully distinguished from rowdy popular meetings in less pristine surroundings. ${ }^{58}$ Yet, as long as there was no constitution - and the possibility of a counterrevolution could not be ruled out - popular societies functioned as a powerful lever and a well of revolutionary energy. For the majority of Batavian revolutionaries, popular societies and associations were a temporary lever in times of revolution, no permanent platforms of political participation.

Moreover, after the French experience, popular societies always raised the spectre of faction. According to the former professor of theology, prominent publicist, and future Batavian national representative IJsbrand van Hamelsveld, there was a real danger to crowds, clubs, and faction. In an exposé addressed to the citizens of Leiden in March 1795 in the Reformed Marekerk and printed afterwards, Van Hamelsveld laid out his view on the means to arrive at the 'good cause of liberty'. He observed that

56 Cf. Oddens, Pioniers in schaduwbeeld, p. 199.

57 As cited in De Wit, De strijd tussen aristocratie en democratie, pp. 123, 167-168.

$5^{8}$ For a similar assessment of Wiselius and Gogel's aversion to political involvement of the lower classes, see Schama, Patriots and Liberators, p. 331. 
[f]action and parties of which France, in the middle of the great attempts of this noble nation, has given us formidable examples, are the consequences of Clubs and Societies that operate separately, that become animated by the spirit of someone who sets the tone, pretends to have special insights, and acts from distinctive principles. - No! The people is an indivisible unity, one body; without uniformity of action based on these very principles, without being aimed at the same purpose, an orderly voice of the people is impossible. ${ }^{59}$

Van Hamelsveld, just like American Federalists and French Thermidorian centrists, conceived of the role of societies and clubs in the French Revolution in terms of a shattering of the monistic, unified body of citizens. He also saw a connection with the political dynamic of crowds: 'Only with trembling and fear can I think of the dismal disorderly assembling of a crowd threatening with destruction; a tumultuous gathering is not a proper voice of the people, not an orderly activity.' Crowds, he went on, are only too easily carried away by 'popular leaders' or 'demagogues who with a glib tongue and gentle words win the people to their side. ${ }^{60}$

Yet, the evaluation of the legitimacy and role of political associations and clubs was much more ambivalent than the harsh rejection of IJsbrand van Hamelsveld appears to suggest. In 1795, a hotchpotch of hundreds of such societies existed throughout the country. Some were revolutionary committees newly founded in 1795 to support the overthrow of the old regime on a local level. Others had grown out of politicized reading societies founded in the early 1790s. And others still stretched back to the 178 os or earlier.61 Revolutionary committees set up in late 1794 promoted the establishment of more popular political 'reading societies' to cultivate and enhance revolutionary consciousness, and create a network of political allies. ${ }^{62}$ Then, again, there were ward meetings, as well as more militant clubs coming together in taverns

59 Y. van Hamelsveld, Vertoog over de middelen, tot voltooijing en handhaaving van de de goede zaak der vryheid; voorgedragen aan de burgerij van Leyden (Leiden: C. de Pecker, 1795), p. 18.

6o Van Hamelsveld, Vertoog over de middelen, p. 18.

61 On Dutch eighteenth-century cultural and literary societies, see Mijnhardt, Tot heil van 't menschdom; De Vries, Beschaven!.

62 Geyl, Geschiedenis van de Nederlandse stam, vol. 3, p. 291; P.J. Buijnsters, 'Lesegesellschaften in den Niederlanden', in: O. Dann, (ed.) Lesegesellschaften und Bürgerliche Emanzipation. Ein europäeischer Vergleich (Munich: C.H. Beck, 1981), pp. 143-158, at p. 154; H. Reitsma, 'Lesegesellschaften und Bürgerliche Revolution in Amsterdam', in: idem, pp. 159-180. See also T. Poell, The Democratic Paradox. Dutch Revolutionary Struggles over Democratisation and Centralisation (1780-1813) (Utrecht, Dissertation, 2007), pp. 91-93. 
and public houses. And finally, primary assemblies were instituted to choose representatives for local, provincial, and national political offices; they could also function as platforms for education and debate. How to distinguish between these various forms of societies and assemblies, and how they related to each other was not always clear and varied from town to town; their role and function were subjects of numerous local conflicts. ${ }^{63}$ Some of the older existing societies were initially artistic, literary, scientific, or philosophical in nature (which is not to say that all these societies became politicized). ${ }^{64}$ Members were often engaged in editing, and writing for, (spectatorial) journals and periodicals. Whereas the Patriot Era witnessed a strong politicization of a number of these journals and societies, this process was interrupted by the restoration of the Orangist regime in the late 178 os. But in the early 1790 s, societies such as Doctrina \& Amicitia, as well as many others, became the cradles for revolutionary thought, and eventually, revolutionary action.

It should come as no surprise, then, that, as in France, political associations and popular societies enjoyed a venerable reputation. Many leading Batavian revolutionaries had intellectually and politically matured in these societies. They had often served as a springboard for their political careers, as in the case of the democratic-unitarists Ockerse and Konijnenburg. ${ }^{65}$ Ockerse's De democraten promoted popular societies as vehicles of enlightened education, political engagement and patriotism, and generally as benevolent platforms for citizen activism. Citizens should be the permanent 'guardians of the constitution' and should be able to voice their criticisms in local, popular meetings so as to avoid the establishment of an 'elective aristocracy' and create a true 'democracy by representation' instead. ${ }^{66}$

The ambiguous stance on the nature and role of popular societies came to the fore in a debate in the National Assembly in June 1797. Earlier, on March 10, 1796, a majority of the representatives had decreed that the right of petition applied to individuals only, not to corporations, societies, or associations, a

63 For Amsterdam, see A. Jourdan, 'Amsterdam klem tussen staat en volk. Een bedreigde municipaliteit (1795-1798)', in: I. Nijenhuis, J. Roelevink, and R. Sluijter (eds.) De leeuw met de zeven pijlen. Het gewest in het landelijk bestuur (The Hague: ING, 2010), pp. 95-110. For Utrecht, see R.E. de Bruin, Burgers op het kussen: volkssoevereiniteit en bestuurssamenstelling in de stad Utrecht, 1795-1813 (Zutphen: Walburg Pers, 1986). On the province of Friesland: J.R. Kuiper, Een revolutie ontrafeld: politiek in Friesland 1795-1798 (Franeker: Van Wijnen, 2002).

64 Mijnhardt, Tot heil van 't Menschdom; De Vries, Beschaven!.

65 See Koekkoek, "Eene waare en vrije republiek"'.

66 De democraten, vol. 1, no. 7, August 4, 1796, 'Iets over de volks-sociëteiten', pp. 49-56; De democraten, vol. 1, no. 11, August 25, 1796, pp. 81-88, at p. 88. See also De democraten, vol. 1, no. 38 , January 26,1797 , pp. $277^{-284}$. 
decision that was prompted by fear of too assertive and potentially disturbing popular societies, and the idea that the popular will cannot and ought not to be expressed by mediating bodies. ${ }^{67}$ In June 1797 , in the build-up to the referendum on the first Ontwerp van Constitutie (draft of constitution), the leader of the radical republicans in the National Assembly, Pieter Vreede, (a former member of the heavily politicized literary Rotterdam society Studium Scientiarum Genitrix) suggested that popular societies be made permanent bodies guaranteed by the constitution. Accordingly they may become legitimate popular societies, schools in which the country's true interests will be taught, minds will be brightened, and hearts will be sparked.' He proposed to constitutionally recognize these 'depositories of freedom' and turn them into permanent platforms for citizen participation. ${ }^{68}$

Representative Jan van Hooff, who had been imprisoned in Paris during the Terror and had closely witnessed the working of the Jacobin clubs, praised Vreede's intention behind his proposal and acknowledged the need for citizens' education and enlightenment. Van Hooff considered societies as an appropriate means to that end. But he rejected Vreede's proposal for installing permanent primary assemblies, as these would bring about a 'permanently deliberating nation'. Even worse, it would 'declare war between the authorities and the people' and 'result in an eternal flow of confusion, which can only end in anarchy'. Moreover, most citizens would be too busy with their own affairs to be able to attend the society's meetings. Hence the meetings would run the risk of being dominated by 'the ambitious' and 'intriguers'. Drawing on the ideal of a monistic body of individual citizens, Van Hooff argued that popular societies ought not to be constitutionally protected because they cannot claim any 'more rights' than a 'private person'. Echoing Van Hamelsveld, he claimed that they cannot become part of the 'body politic', the 'sovereignty of the people is after all one and indivisible.' Van Hooff pointed out that in France 'the societies which assumed the right of the entire people or were affiliated with the société mère called the Jacobins, were destroyed'. They 'not only controlled the constituted authorities' but also 'rivalled with the National Convention', chasing away 'true patriots' and trying 'to destroy the national representation'. In the end most representatives agreed with Van Hooff that a permanent involvement of primary assemblies would interfere with the indivisibility of the people's sovereignty as represented in the National Assembly. ${ }^{69}$ Vreede's

67 Oddens, Pioniers in schaduwbeeld, pp. 164-165.

68 Dagverhaal 6, no. 561, June 13, 1797 (session May 26), p. 117.

69 Ibid., pp. 117-118. 
proposal was voted down. But the debate shows that the French experience with political clubs bequeathed an ambiguous legacy to ponder.

Another consequence of the Terror was that, apart from a few radical republicans, most Batavian revolutionaries invoked this violent episode as a warning for what they considered the lower, uneducated classes. Again, the revolutionary language they used - of equality and (universal) natural rights - can be deceptive here. It is crucial, however, to observe that one of the mouthpieces of radical Batavian republicanism, the journal De democraten, also uttered serious doubts concerning the fitness of certain classes of people for full political citizenship. ${ }^{70}$ If there was one thing the Terror had demonstrated, De democraten in January 1797 suggested, it was that 'the general corrupted state of humanity requires tighter curbs. ${ }^{71}$ Such precautions would especially apply to what De democraten referred to as the 'rabble, the major part of a population.' ${ }^{72}$ The journal's observation that this substantial social class usually 'adheres to the dominating party' and 'is disposed to looting and assaulting' actually seemed to contain a double reference: to the Paris mobs as well as to the marauding bands of Orangists of 1787 , the memories of which were all but forgotten among ex-Patriot Batavians. It behaves 'savagely when it is stirred', but 'trembles when confronted with some bayonets or a handful of police officers'. The 'fatherland's rabble', De democraten asserted, 'consists of a bunch of children that necessarily requires leading reins.' A sound revolution, the suggestion went, ought not to depend on them..$^{73}$ The French experience had revealed

70 Wyger Velema, and following in his footsteps, Mart Rutjes, have recently underlined the importance of the classical-republican tradition as one of the principal sources that shaped Batavian visions of citizenship, even though they point out that this 'classical' republicanism was informed by an (enlightened) egalitarian natural rights discourse. More specifically, they identify the ideal of political participation and display of disinterested civic virtue as the defining aspects of the more radical conceptions of citizenship put forth during the Batavian Revolution. My point is that the Terror threw an ominous light on the ideal of the participatory citizen and the phenomenon of popular societies as platforms for citizen activism. It brought to light the risk of involving those who were designated as the lower, uneducated classes. Even for radical Batavian republicans the ideal of active citizenship was more coloured by the Terror than Rutjes and Velema allow for. Velema, 'Republikeinse democratie'; Rutjes, Door gelijkheid gegrepen, pp. 18-21. See also Velema, Republicans, pp. 179-200.

71 De democraten, vol. 1, no. 38, January 26,1797 , pp. 277-284, at p. 280.

72 Rutjes contends that the distinction between 'people' and 'plebs' or 'citizens' and 'the rabble' disappeared completely in the period ${ }_{1795}-1801$. Although it might be true that the specific terms 'gemeen' or 'grauw' (rabble/mob), etc., were not often used, the evaluation of Batavian revolutionaries of 'the people' was much more complicated than Rutjes appears to suggest. Rutjes, Door gelijkheid gegrepen, pp. 127-128.

De democraten vol. 1, no. 38, January 26, 1797, p. 282. 
that the 'middle class' ought to be 'the support, the most useful part of any state' and that in this middle class one can find 'most honesty, most patriotism, most enlightenment'. Among them 'one can find the purest conceptions of revolution.' '[T] he happiness of the state', De democraten concluded, 'depends on this distinguished part of the people'. Yet, the journal lamented that it was in this very same class that one would 'discern little spiritedness and most lethargy'. ${ }^{74}$ Reflecting on the Jacobin regime, De democraten, thus, articulated who should be the principal bearers of modern citizenship in the Batavian Republic. Behind the declared and abstract defences of popular sovereignty and representative democracy, lay a deep suspicion of the actual involvement of the lower classes in politics.

The alleged impressionability of 'crowds' as Van Hamelsveld put it, or the 'rabble' in the words of De democraten, was shared by a considerable number of Batavian revolutionaries. Consider the theologian, Zeeland politician, and future minister of education and professor of oriental languages at Leiden University, Johannes van der Palm, who in 1795 gave an address in the Vaderlandsche Sociëteit (Patriotic Society) of Middelburg (Zeeland) on the problematic notion of 'popular favour'. After the invasion of the Batavian-French troops in January 1795, Van der Palm had swiftly worked his way up in Zeeland urban and provincial politics and became a member of several committees including the Assembly of Provisional Representatives of Zeeland in $1795^{-1796}$. Although a declared supporter of the Batavian revolution, Van der Palm was very much on his guard against what he diagnosed as the inconstancy of the public's judgment and its passionate nature. ' $[\mathrm{N}]$ othing is more ferocious and fickle than the favour of the people', he impressed his audience in 1795:

We're not the Marats, the Robespierres, whose memory has become a curse and horror, once gods worshipped by the people, who voluptuously kissed their blooded hands, and kneeled down for the disgraceful guillotine as well as for the holy altar of the Fatherland? ${ }^{75}$

As these comments by De democraten, Van Hamelsveld, Van Hooff, and Van der Palm demonstrate, the Terror had left a deep impression on them. Their fears of the manipulability of the mass, the inconstancy of popular favour, and the

74 De democraten, vol. 1, no. 38, January 26, 1797, p. 282.

75 J.H. van der Palm, Redevoering over de volksgunst. Uitgesproken te Middelburg in eene vergadering van de Vaderlandsche Sociëteit (1795)', in: J.H. van der Palm, Redevoeringen, verhandelingen en losse geschriften, 5 vols. (Leeuwarden: G.T.N. Suringar, 1854-1855), V, pp. $36-44$, at p. 38 . 
tumultuous nature of public gatherings, as well as the danger of faction caused by popular societies, were articulated in response to the revolutionary situation in the Batavian Revolution but were also informed by the French experience.

So far we have seen that the Terror became an important point of reference in debates about the constitutional embedding of citizenship, the channelling of political participation, the fear of involving the mass in politics, and the contested role of popular societies. However, in their efforts to promote popular societies as appropriate vehicles of revolutionary mobilization and education, radical republicans also sought to dispel the widespread fears of Jacobin scenes. They argued that it was simply not to be expected that Batavian popular societies would be dominated by demagogues and bring about immense disorder as had been the case in France. Certainly, the Terror had shown that the French constitution of 1793 was harnessed, as De democraten put it, with too few 'clamp springs' and 'means of coercion. ${ }^{76}$ However, the supposedly fiery 'temperament' of the French was seen as another chief cause of the excrescences of the French Revolution. Downplaying the risk that Dutch popular societies would become dominated by demagogues (as had happened in France), since the Dutch allegedly possessed a calm and quiet temperament, became a recurring argumentative strategy. Contrasting the Dutch national temperament with the French one and drawing on the bloody consequences as displayed in recent French history, was moreover not a line of argument exclusively employed by one group in particular. It was a widely shared assumption among Batavian revolutionaries. Yet, there was a variety of ways in which it was put to use. In a broader sense, emphasizing these contrasts contributed to the conception that the Dutch should arrive at their own national model of citizenship.

Thus, according to the unitarist representative Jacob van Manen, "The wellknown incontestable national character or disposition of the Dutch' is 'one of the main things one ought to take into consideration when devising a constitution.' The French served as the ultimate foil in such statements, for 'isn't ours quite the opposite of the French national character?'77 The point these representatives wished to convey was not only that the Terror was unlikely to ever happen in the Batavian Republic. They also insisted that the Dutch need not

76 De democraten, vol. 1, no. 38, January 26 , 1797 , pp. $277-284$, at p. 280.

77 Dagverhaal 3, no. 254, November 22, 1796 (session November 18), pp. 678-679. 
necessarily follow the French in their institutional response to the Terror. The dismissal of the French system came especially to the fore during a debate in early February 1797 over the question whether the legislative power should be divided over two chambers. Representative Johan Huber's proposal that the Batavians should adopt the French system of a Conceil des Anciens and a Conceil des cinq-cents, met with strong objections. Huber observed that the Dutch were lucky to have 'learned wisdom and prudence' from the French experience, the 'School of Misfortune'. The 'licentious constitution of 1793', this 'Law book of Anarchy', he argued, should never be our 'guide'. Huber then went on to praise the French constitution of 1795, advocating a two-chamber legislative system for the Batavian Republic on that basis.

Huber's characterization of the Jacobin constitution of 1793 as 'anarchical', however, did not make a strong impression: by 1797 that was a truism to most of his colleagues. But whether his implication that the Dutch, therefore, ought to adopt the French institutional response of a two-chamber legislation was justified, was quite another matter. Jacob Hahn, one of the most vocal and prominent representatives of the National Assembly, disagreed fiercely with Huber: 'It is wrong, it is disadvantageous, it is most dangerous even to invoke the constitutions of the French like that', he cried out. 'I believe it befits the representatives of the free Batavian people [...] to maintain our independence to the highest degree'. Hahn acknowledged that the French may very well be content with their own 1795 constitution, but 'we speak for The Netherlands, and for The Netherlands only! 78 Representative Herman Vitringa wholeheartedly agreed: 'the scenes in France' were of course of great value, especially the lessons they provide 'regarding the consequences of irregular desires, passions, and weaknesses'. But 'in the arrangement of their state', he pointed out, the French 'had to take into consideration reasons and circumstances that are not ours'.79 Not only was the Terror thought to be a kind of phenomenon alien to the Dutch national spirit, the very absence of this particular experience in the Dutch revolutionary process confirmed the national particularity of a reinvented Dutch republic, and the legitimacy of including in it a nationally conceived 'Dutch' model of citizenship.

This - sometimes strained - combination of intellectually incorporating the lessons of the French experience of the Terror, while simultaneously setting it apart as something peculiarly 'French', was also Ockerse's principal way of dealing with the Terror. Ockerse's earlier dismissal of the Jacobin constitution of 1793 and his praise of the Thermidorian constitution of 1795 by no

78 Dagverhaal 4, no. 369, February 10, 1797 (session February 6), pp. 797-798.

79 Ibid., pp. $798-799$. 
means implied that he thought that the latter should be automatically transposed to the Batavian Republic. If the constitution of 1795 was 'perhaps the best the French could have ever devised for themselves', as De democraten had put it in August 1796, it was quite another question whether this constitution is 'the best and most appropriate' for the 'phlegmatic Batavian nation', a nation of hardly two million people, most of whom were in trading business, and moreover, 'have been living under a republican form of government for almost two centuries'. ${ }^{80}$ The 'best' constitution, Ockerse believed, rehearsing a commonplace in political theory from Aristotle to Montesquieu, is, in short, a relative notion. Ockerse held that a constitution should be entirely adapted to the 'character' of a nation.

Ockerse's preoccupation with the 'character' of a nation was not incidental. He had developed, and was in 1796-1797 still in the process of developing, his thoughts on 'character' in a major three-volume exposition Ontwerp tot eene algemeene characterkunde (Sketch of a General Science of Character), the volumes of which were separately published in 1788,1790 , and $1797{ }^{81}$ In these works, Ockerse aimed to offer a systematic exploration of the concept of character, by which he generally understood that composition of features through which someone or something may be distinguished from something else. The scope of his investigations ranged from the character of individual human beings to social classes and professions, and from small communities such as villages and cities to larger social units, such as peoples and nations, and finally even the character of entire centuries - in particular the one he was living in. ${ }^{82}$ His expertise in this field and his commitment to this mode of sociocultural enquiry led him to examine the issue of the most appropriate constitution for the Dutch Republic comparatively and in light of recent experiences. A number of issues of the journal De democraten clearly can be seen to echo the third volume of his Ontwerp which was basically concerned with the study of national characters and came out in 1797. On the most fundamental level, Ockerse maintained (echoing Montesquieu) that national characters were formed

8o De democraten, vol. 1, no. 11, August 25, 1796, pp. 81-88, at p. 83 .

81 W.A. Ockerse, Ontwerp tot eene algemeene characterkunde, 3 vols. (Utrecht: G.T Paddenburg; Amsterdam: J. Allart, 1788-1797).

82 The first volume received several mixed reviews in Dutch magazines, as well as a twelvepage positive review in the French Journal encyclopédique (1788) and another long, mainly positive, review in the British Monthly Review (1791). For this see, J. Stouten, Willem Anthonie Ockerse (1760-1826). Leven en werk. Het bewogen leven van een verlicht 'Bataafs' politicus, letterkundige, predikant en wijsgeer en zijn veelzijdig oeuvre op de overgang van de achttiende naar de negentiende eeuw (Amsterdam: APA-Holland Universiteits Pers, 1982), pp. 69-81. 
by geographical location and climate, which entails that one can find among various nations a variety of means of subsistence, needs, facilities, and mores. One would find, then, that peoples vary in temper and passions. Around the same time that national character was discussed in relation to a new constitution in the National Assembly, Ockerse's De democraten asserted that the Frenchman is 'quick, comprehends swiftly, decides immediately', while 'his passions are easily moved'. During the recent French revolution, there were men who 'abused their [the French people] zeal with specific intentions' and 'induced the people to take rash steps' and accept 'unthoughtful decrees'. ${ }^{83}$ Ockerse went on to explain that popular mass meetings in a central 'colossal city' such as Paris, which were the centre stage of revolutionary action, were particularly attractive to fortune seekers, idlers, and demagogues. Urban crowds were accordingly prone to be carried away by passion. In contrast to the French, De democraten maintained, the Dutch nation is 'phlegmatic, calm and easily satisfied, frugal and counselling, even in times of opulence'. He attributed to the Dutch nation a 'strong craving for liberty' and a certain 'conceitedness which takes no advice'. ${ }^{84}$ Even in times of revolution, then, 'as much as the heated Frenchman must be soothed, the sluggish Dutchman must be galvanized' ${ }^{85}$ Because of this difference in national temper, Ockerse did not fear French excesses, for 'our Nation is not susceptible to tragic scenes that disgrace humanity, not susceptible to a reign of terror.'86

On the contrary, radical Batavian revolutionaries were rather impatient with the National Assembly, as negotiations over the new constitution proceeded too slowly to their liking. In late July 1797, just before the first Ontwerp van Constitutie (Draft of Constitution) would be rejected by an overwhelming majority and Dutch constitutional debates seemed to end in hopeless deadlock, Ockerse held that while 'France has provided us a warning, a powerful example of the consequences of a terrorist administration', the pendulum of French political sentiment had swung to the other extreme, that is, to a 'too exaggerated moderation'.87 The aversion to 'exaggerated' moderation even led some radical publicists, such as Pieter 't Hoen in his journal Nieuwe Post van den Neder-Rhijn to rescue and defend 'Jacobinism' against 'bitter and unjust

\footnotetext{
83 De democraten, vol. 1, no. 38, January 26 , 1797, pp. 277-284, at pp. 278-279.

84 Ibid., p. 280.

85 Ibid., p. 282.

86 De democraten, vol. 1, no. 38, January 26 , 1797, pp. 277-284, p. 283. For a comparable claim that the Dutch are not susceptible to the dangers of popular democracy as the French had been, see the letter of the Batavian constitutional committee to the French envoy Delacroix of March 5, 1798. Colenbrander, Gedenkstukken, II, pp. 190-194.

87 De democraten, vol. 2, no. 64, July 27, 1797, pp. 181-188, at p. 186.
} 
judgements'.88 Based on the fear that after two years of deliberation without any concrete results, the Batavian revolutionary fire would peter out like a damp squib, the moderate Thermidorian regime ceased to be an attractive model. In this process, the Terror and the Thermidorian reaction were turned into specifically French phenomena of the recent past. They were not considered general features or necessary phases of a revolution. Batavian revolutionaries rejected the French revolutionary 'script' ${ }^{89}$ Part of the reason for making this argument was the effort to legitimize and clear the way for revolutionary action. The isolation of, and distancing from the Terror, and more generally the emphasis on a divergence of revolutionary experiences then, contributed to the 'nationalization' of the Dutch revolution, and hence to the conceptualization of citizenship in national terms.

\section{The End of the Democratic-Republican Citizen}

Whereas until January 1798, to many the Batavian political experiment almost seemed to succumb to a lack of political decisiveness, there was no shortage of political action in the following period. Between January 1798 and October 1801, the Batavian Republic witnessed as many as three coups d'état and two constitutions. Amidst this chaos the general trend was that politicians in executive positions during these years assumed power to the detriment of the legislative branch. The 'public' - of citizens, journals, popular societies, pamphleteers - was put on the side line. Meanwhile, French pressure was building; none of the three coups would have been possible without their backing.

The immediate cause for the change in political climate was the defeat by an overwhelming majority of the first Ontwerp van Constitutie (Draft of Constitution) in a referendum held on August $8,1797 .{ }^{90}$ In the months preceding the referendum radical republicans had mounted a successful campaign against it, issuing pamphlets and making full use of the political journals and network of political societies they had at their disposal. They viewed the constitutional draft as seriously defective. Their main objection, in a nutshell, was that the

88 Nieuwe Post van den Neder-Rhijn, vol. 3, no. 149, August 29, 1797, pp. 1217-1224 at p. 1217.

$89 \quad$ K.M. Baker and D. Edelstein (eds.) Scripting Revolution. A Historical Approach to the Comparative Study of Revolutions (Stanford, CA: Stanford University Press, 2015).

9o In total 136,716 voters had cast their vote. 108,761 (79,6\%) voted against, $27,955(20,4 \%)$ voted in favour of the draft constitution. 
proposed constitution contained too littles afeguards for meaningful political participation and influence of the people. ${ }^{91}$ Just before the constitutional referendum, new elections for a second National Assembly had already been ordered. The installation of the second National Assembly in September, thus, coincided with her predecessor's failure of arriving at a constitution. Among the radical republicans, whose numbers were strengthened, and whose selfconfidence had grown after the rejection of the constitutional draft they had put so much effort into discrediting, a sense of urgency took hold that the impasse demanded unconventional measures.

On January 22, 1798, a coup d'état was executed by, among others, Konijnenburg, Ockerse, and Vreede. Crucial was the military backing of the then French envoy Charles-François Delacroix. A new constitutional committee, staffed by among others Konijnenburg and Ockerse, the committee's leading member and spokesperson, soon set to work to draft a new constitution. Theirs was more democratic, centralized, and egalitarian than the draft of 1797. It was put to the vote in a referendum on 23 April and accepted on May 1, 1798. The Staatsregeling (constitution) of 1798 replaced the old, decentralized state structure of the Dutch Republic of the seven provinces with a unitary, centralized state. It was ruled by a national parliament composed of democratically elected representatives. The individual rights of citizens, including the equal legal status of religious convictions, were laid down in the constitution. Those who qualified for full citizenship including the right to vote, that is, those who were over 20 years of age, paid taxes, had resided in the Dutch Republic for the last two years, were able to read and write in the Dutch language, and had signed a civic oath - were now citizens of a unified Dutch nation-state. ${ }^{92}$

The coup d'état, however, created more division and less national unity than ever before. Despite all their spirited talk about democratic participation in the preceding three years, the radical republicans' seizure of power was hardly a sign of their commitment to participatory citizenship. Not only the National

$91 \quad$ Velema, Republicans, p. 197.

92 Women were excluded from the right to vote, as were those who had declared an oath to a foreign power, domestic servants, the needy who relied on, or lived in, workhouses and mental institutions, wards of court, those who were bankrupt and/or in receivership, and those who were indicted by a court of law. The oath of loyalty to the Batavian Republic read: 'I hold the Batavian people to be free and independent, and promise my loyalty to it. I declare my constant aversion to the regime of the stadholder, federalism, aristocracy, and anarchy. I promise that, in all my actions, I will dutifully follow all regulations of the constitution, and never will hand over my vote to someone who I deem to be an advocate of the stadholder, a federalist regime, aristocracy, and anarchy.' 
Assembly was purged from moderate (or anti-unitarist) representatives after 22 January. On May 4 it was also decided by the (temporarily installed) Constituent Assembly that two thirds of its members would stay on in the legislative body to be formed after the newly ordered elections. In addition, in the months following January 22, primary assemblies (grondvergaderingen) were on a national scale disposed of (potential) opponents of the new democraticrepublican regime. In some places up to thirty percent of the electorate was scrapped from the voter registers and thereby deprived of their right to vote. This measure especially bred bad blood as it also implied the deprivation of the right to public office and retirement payments. Civil servants that were suspected of anti-democratic-unitarist sympathies were removed. ${ }^{93}$ Finally, primary assemblies came to be restrained by article 18 of the constitution. This article stipulated that in primary assemblies, citizens were only allowed to vote, not to discuss matters. Popular societies were furthermore denied the right to act publicly and correspond with each other (much like the Thermidorian measure against popular societies of mid-October 1794). On paper, popular societies were tolerated as long as they refrained from political activities. In reality, however, many local revolutionary committees, ward meetings, and political clubs were dismantled - and not only those opposing the new regime. ${ }^{94}$ The Friesche Courant (Friesland Courier) of February 3, 1798, announced that the future constitution 'restrains the political rights of citizens in the circle of primary assemblies, and will regulate one's means and capacity to organize in distinct societies, [and] involve oneself in politics [...] in such a way that these societies will never cause any disturbances. ${ }^{95}$ Local democratic elections for city councils, provincial assemblies (and occasionally civil servants) were eradicated and replaced by a system of assignment by the central authorities.

Through all these measures the new regime sought to secure its fragile power base. Yet, in doing so, they simultaneously undermined it. The high tide of democratic-unitarist reign was short-lived. The new government lacked a firm local power base and had antagonized many with their purge of local primary assemblies and imprisonment of political opponents. The decision that only one-third of the seats of the present Assembly would be open for re-election

93 Oddens, Pionier in schaduwbeeld, pp. 322-336.

94 Kuiper, Revolutie ontrafeld, pp. 429-437; Jourdan, 'Amsterdam klem tussen staat en volk'. In his discussion of 'Representative democracy and republican participation', Velema omits to mention the large-scale purge of, and restrictions placed on, primary assemblies, as well as the closure and restraining of popular societies after January 22. Velema, 'Republikeinse democratie'.

Friesche Courant, 3 February 1798. As cited in: Kuiper, Revolutie ontrafeld, p. 419. 
seemed even to moderate supporters of the new regime a blatant violation of their own professed constitutional principles. With the blessing of then French minister of foreign affairs Talleyrand, a second coup d'état was executed on June 12, 1798, by a motley crew of moderates, general Daendels, and some from within the very own ranks of the radical republicans of January 22. Their takeover further contributed to the disintegration of the democratic-republican infrastructure, as now the radical clubs supporting the January 22 regime were also swiftly dismantled and a significant number of political journals were censored. ${ }^{96}$ Ironically, then, the political coup of January, together with the coup of June 1798 , virtually destroyed grass-roots democratic participation, its infrastructure, and perhaps even more important, its spirit. The radical phase of the Batavian Revolution of January-May 1798, which undeniably constituted a breakthrough in Dutch constitutional and institutional history, was not the zenith of democratic-republican citizenship, but the beginning of the end of it. Those who looked upon it with disappointment, could not help to relate this domestic experience to the authoritarian course the French Revolution had taken since 1797. Oppression, violating the constitution, eliminating political opponents: the radical phase of the Batavian Revolution became identified with the French experience, and more generally, with the failure of the age of revolutions and its underlying principles.

June 1798 heralded a new phase of reconciliation, nationalization, and depoliticization. In a famous and often quoted letter of June 26 to Samuel Wiselius, Jacob Spoors, one of the foremost perpetrators of the June coup, expressed the sentiment thus: 'Our politics is entirely new [...] It is nothing else than being strictly honest, affronting all intriguers, putting into operation and nationalizing the constitution, so as to once and for sweep away all the basis for all faction. ${ }^{97}$ In fact, Spoors's claim that politics as of June 1798 would be 'entirely new' was a grave exaggeration. The constitution of May 1, after all, was left intact. The framework of nationalization and reconciliation was a centralized state structure, at least on paper. And as people were fed up with the ineffective, impotent national representation torn apart by faction and disputes, the cry for 'nationalization' could be heard everywhere.

By 1801, many politicians deemed the effectiveness of Batavian government profoundly inadequate. A third coup d'état was executed by a minority of

96 De Bruin, Burgers op het kussen, pp. 173, 186, 198-199; M. Prak, Republikeinse veelheid, democratisch enkelvoud. Sociale verandering in het revolutietijdvak, 's-Hertogenbosch 17701820 (Nijmegen: Sun, 1999), pp. 250-252.

97 Colenbrander (ed.) Gedenkstukken der Algemeene Geschiedenis van Nederland van 1795 tot 1840 , vol. 3, p. 442 . 
executive government officials. The constitution was pushed through under the pretence of a democratic referendum; the legislative body was basically dismantled; an executive council assumed all power, and the word 'republic' was dropped. The new regime of 1801 proclaimed that the new constitution was a product of 'duty, patriotism, and experience', that is to say, of the experience that 'discord, discontent, and the desire for change' had wreaked havoc. The new constitution, they argued, would make an end to this.

The new political climate of the years around 1800 also produced corresponding concepts of citizenship. Illustrative is the journal Burger politieke blixem edited by the dyed-in-the-wool patriot and revolutionary Bernardus Bosch, who was thrown out of the halls of power after the coup of June 1798. He started two weekly journals, De heer Janus-Janus zoon and Burger politieke blixem. ${ }^{98}$ The mission statement of his new Burger Politieke Blixem commenced by addressing all 'Bataven, Patriotten, Anti-Patriotten, Foederalisten', etc. ${ }^{99}$ Bosch's journal called for the prevention of 'all clashes within the constituted powers', the combining of 'mutual interests', the 'concordance of laws, the vigilance of the courts of police and justice', the promotion of 'order and duty', a resilient and clearly expressed 'will of the nation', and the 'unification of factions.'100 The French Terror 'that took place in our century in front of our eyes' remained a cardinal point of reference: 'The bloody pillars on which the French Republic rests provide us a series of terrifying consequences of popular discord and clashes within government, from which every human sentiment shiveringly recoils, but nonetheless serve as an important lesson.101 To prevent such discord and recklessness, when 'the laws remain silent', one has to realize that a people ought to governed 'according to their national character [...] according to inbred parental prejudices'. This, Bosch argued, 'is the best way to keep the balance of popular sentiment steady' and reconcile different points of view. ${ }^{102}$ By way of concluding his mission statement Bosch announced that Burger politieke blixem 'will make it its sacred duty to alert the people, and urge good citizens to perform the duties that characterize the honest, [public] interestgenerating patriot, family man, industrious husband, affectionate son [...] present in every class.'103 This language of Bosch's journal was markedly

98 On Bosch and his journals, N.C.F. van Sas, 'De Republiek voorbij. Over de transitie van republicanisme naar liberalisme', in: Grijzenhout, Velema, and Van Sas (eds.) Het Bataafse experiment, pp. 65-100, 310-313.

99 'Opdracht', in: Burger Politieke Blixem 1 (1800). The first issue appeared on April 15, 1800.

100 'Opdracht', in: Burger Politieke Blixem 1.

101 Ibid.

102 Ibid.

103 Ibid. 
different from his earlier high-spirited writings and speeches. His 'national' citizenship ideals, put in contrast with the French revolutionary experience, were no longer meant to energize a revolutionary people but intended to reach a broader Dutch audience sick of discord and faction.

In the different circumstances of 1800-1801, former radical republican revolutionaries like Bosch struck a tone of melancholy, disillusionment, and criticism, for example about the gradual return and acceptance of Orangists, in public life, discourse, and office. As a revolutionary who had fervently subscribed to the ideal of civic equality, Bosch now bitterly observed that the 'titles of burger and burgeres were again replaced by those of Madame and My Lord'. 'Everything', he lamented repeatedly in his journal, 'slowly and gently turns back to the way it was.. ${ }^{104}$ Bosch was among the first to notice that the well-todo class gradually resumed their old administrative offices and positions as in the old days. "The old traits of being distinguished, respectable, rich, moral, and capable, has nowadays again become a requirement.'105 A fictive letter from Paris in De heer Janus Janus-zoon reported a comparable change of climate in France: 'No-one speaks any longer of the factions of Jacobins, Royalists, Moderates, etc..' The 'word patriot is seldom heard - nor is the word Citoyen'.106 In another fictitious dialogue between a regent and a farmer, which did not necessarily reflect Bosch's views but should be read as his impression of the temperature of public opinion, he portrayed the farmer as totally disillusioned after years of revolution; the regent judged that the people were not yet enlightened, not ripe, not virtuous enough for revolution. The principles of the revolutionary era were appealing in theory, the regent said, but inapplicable in practice. ${ }^{107}$

The waning influence of radical republicans and their removal from the centre of power encouraged Orangist publicists to let their voices be heard again in public writing. Generally their tone was one of unity behind the fatherland, but theirs was a unity from which revolutionary republicans were explicitly excluded - revolutionaries, according to one venomous Orangist publication of the time, who had been educated in the 'School of Robespierre'.108 One such Orangist voice was Johannes le Franq van Berkhey,

104 Burger Politieke Blixem 1, No. 2, pp. 9-16, at p. 13. He repeated this lamentation in issue 49 of 16 February 1801, pp. 397-404, at p. 403. Burger Politieke Blixem 1, No. 5, pp. 33-40, at p. 34.

105 Burger Politieke Blixem 1, No. 5, pp. 33-40, at p. 36.

106 De Heer Janus Janus-zoon, no. 14, 30 July 1801, pp. 105-112, at p. 106.

107 Burger Politieke Blixem 1, No. 6, pp. 41-48.

108 [Anonymous], Bedenkingen over den tegenswoordigen staat van Nederland (Amsterdam: M. de Bruin, 1802), p. 132. 
an ardent Orangist physicist, poet, painter, and author of a multi-volume natural history of The Netherlands, who in 1801 published a lengthy poem entitled De Bataafsche menschlijkheid of de gevolgen der tweedracht: betoogt uit de rampen van het vaderland in vijfhonderd twee-en-zestig scherpdichterlijke sluitvaerzen en rondborstige vraegen naer de rechten van den mensch voor de tribune der eendracht (Batavian Humaneness or the Results of Discord: Based on the Disasters of the Fatherland in two hundred sixty-two Sharp Poetical Verses and Plain Questions about the Rights of Man before the Tribunal of Concord). ${ }^{109}$ Van Berkhey fulminated against Bosch's two journals, the relatively moderate tone of which had not made a huge impression on him. Former revolutionaries could do no good anymore. According to Van Berkhey's poem, the blame for civic discord and faction could only be put on one group: the revolutionary republicans. Verse after verse, he related them to the French 'acerbic Jacobins' who had committed 'thousands evil deeds' and 'barbarous inhumaneness', making use of the guillotine, the 'instrument of murder'. The poem mocked the revolutionaries' principles, their 'political science, their professed 'indomitable humaneness', their inciting of 'rage' and 'faction', and their spurring of 'the rabble to mutiny'. At the same time, the poem revealed what a renewed depoliticized and patriotic citizenship from an Orangist perspective would amount to. As verses 165 and 202 read:

If a tranquil citizen seeks to remain Outside of people and government If he longs for peace and quietness And does not wish to encourage discord Then he will never lose his right On nature and humaneness

And on the Batavian revolutionaries:

Thus People and City are abandoned, Was it Honest, Dignified, Dutifully The citizenship of the Batavian? Are they subjects of welfare?

109 Le Francq van Berkhey's De Bataafsche menschlijkheid of de gevolgen der tweedracht: betoogt uit de rampen van het vaderland in vijfhonderd twee-en-zestig scherpdichterlijke sluitvaerzen en rondborstige vraegen naer de rechten van den mensch voor de tribune der eendracht (Leiden: J. van Thoir, 1801) appeared under the pseudonym Janius Laconicus Franco Batavus. 
Or is it disloyalty

To the duties of humaneness?110

The disparagement and condemnation of Orangist publicists of Batavian revolutionaries, and their somewhat easy rhetoric of identifying them with Jacobin terrorists, is not surprising given that the political tide had turned. They had regained self-confidence and hated the Batavian Revolution and its antiOrangist agenda.

In this light the extent to which former revolutionaries distanced themselves from their former commitment to what they considered to be principles of an Atlantic age of revolutions is all the more remarkable. One of the principle ideologues and revolutionary leaders of January 22, Willem Anthonie Ockerse, represents this moment of disillusionment more than anyone else. After the coup d'état of June 12, 1798, Ockerse had ended up in prison. He was soon released, but his role as politician was played out. In a lecture in March 1803 to the society Doctrina et amicitia where he regularly gathered with some of his old partners in revolution Wiselius and Gogel, Ockerse reflected:

We have lived through the age of revolution, seen the world republicanize; but did we not at the same time see so much horrors, and was this republicanizing not too dear a price to pay, soured our hearts to such an extent, that we, together with our brothers of the entire globe, are fed up with it for a century or so? 111

Ockerse's evaluation was that 'fraternity' had incited 'terror' and brought Europe 'death'. It had proved impossible and too early to reap the political benefits of enlightened sociability.

In a follow-up lecture the next year, Ockerse came to see the political translation of high-minded citizenship ideals as an utter failure. It is worthwhile to quote Ockerse at length here. He did not deny that '[e]very member of society has a fixed inclination [...] to fully reclaim his natural right'. But

110 Le Francq van Berkhey, De Bataafsche menschlijkheid of de gevolgen der tweedracht, pp. 43, 53 .

111 W.A. Ockerse, 'Verhandeling over der menschen neiging tot gezelligheid; en over de beste middelen, om die neiging aan het algemeen geluk dienstbaar te maken. Eerste gedeelte. Voorgelezen in genootschap Doctrina et amicitia den 14den Maart 1803', in: idem, Redevoeringen, nagelaten door W.A. Ockerse (Amsterdam: Johannes van der Hey en zoon, 1826), pp. 171-194, at pp. 188-189. 
[i]f this natural instinct is aroused by misrule and oppression, it deteriorates into rebelliousness, and ends in national revolt. This was the true source of France's, of Europe's latest revolutionary impulse. For many years, dissatisfaction was brewing. Great philosophers, a Montesquieu, Rousseau, Voltaire, Barbeirac, Raynal, and others, fuelled it by recommending a philosophical design to improve the organization of society. The sweet poison was gulped down; the spastic convulsion broke out in raging anger. - A general enthusiasm of popular rule spread like the bubonic plague from one people to another. - The chosen cruelties became child's play to a gentle people, to a most civilized continent; and like all excesses of enthusiasmus, the revolutions destroyed themselves; like Saturn they devoured their own children; peoples, on their Icarus-wings too close to the sun of imaginary perfection, plump into a cesspool of superstition and misery deeper than ever before; in a word, the idea of a philosophical restoration of societies has failed completely.12

A general disillusionment, then, took hold of a generation of Batavian revolutionaries of which Ockerse was its most eloquent spokesman. The depoliticized citizenship ideals that came to dominate the period 1798-1801, and after, diverged strikingly from - and were often defined in opposition to - the revolutionary fervour of the early 1790s. The transatlantic mind set, the sense of sharing in a common project of citizen emancipation, was substituted for a depoliticized and nationalized citizenship discourse that would shape Dutch political culture for decades to come.

112 W.A. Ockerse, 'Verhandeling over den menschen neiging tot gezelligheid; en over de beste middelen, om die neiging aan het algemeen geluk dienstbaar te maken', in: Redevoeringen, nagelaten door W.A. Ockerse (Amsterdam: Johannes van der Hey, 1826), pp. 195-216, at pp. 202-204. 